Jap. J. M. Sc. \& Biol., 9 , 41-44, 1956

\title{
AREAL GROWTH AND CELl POPULATION IN TISSUE GULTURE
}

\author{
KOUICHI TAKANO1) AND MASA-ATSU YAMADA2) \\ Department of Pathology, National Institute of Health, Tokyo3) \\ (Received: February 22nd, 1956)
}

Among several methods for the growth estimation of tissue cells cultivated in vitro, the measurement of areal growth of cell colonies has been most generally used. Ehrmann and Gey (1953) improved the procedure of areal measurement so that the indirect method became considerably reliable. Sanford et al. (1951) devised a more precise quantitative method of enumeration of cell nuclei on the basis of a procedure of preparing replicate cultures (Evans et al., 1951).

The HeLa strain cells used in our experiments grow on the glass wall forming colonies of almost monolayer even if they are implanted as a homogeneous suspension of single cells. Besides the colonies can be readily disintegrated into single cells by the treatment with trypsin or citric acid. Therefore, both measuring techniques mentioned above are applicable to the cells.

In the present paper, some methodological considerations in the practical use of both techniques and the correlation between colonial area and cell population are discussed using the HeLa strain cells as the object.

\section{MATERIALS AND MethodS}

The basic cultural conditions, preparation of replicate cultures for experimental procedures, technique of nucleus enumeration, and evaluation of the method in practical use were described in detail in the previous report (Takano, Yamada and Yaginuma, 1956).

The procedure of areal measurement of cell colonies is as follows: The magnification of microscope is fixed at $5 \times 2$; the maximum and minimum diameters of a colony on the wall of a square-shaped tube are measured with a fine lattice inserted in the ocular lens, values not attaining one scaling unit of the lattice being neglected; the area of each colony is expressed in terms of the product of both diameters; the total area of all colonies included in each tube is thus calculated; and the averaged area of a group of 3 to 6 replicate cultures are considered to represent the value at one observation time. Such a measurement is repeatedly performed with certain regular intervals upon the same cultures.

The procedure described here is simpler than that previously reported by Takano and Yamada (1955) in that no consideration of the size, number and position of explants is required.

1) 高野宏一・2)山田正篤，3)国立予防衛生研究所病理部 


\section{RESULTS AND Discussion}

Increase in cell number: The results of analyses of the growth mode of the HeLa cells on the basis of enumeration of nuclei have been already reported by Yamada and Takano (1956). An example of growth curve is given here in Fig. 1. The lower curve of the figure shows the actual cell numbers counted and the upper one logarithms. A statistical analysis has revealed that the upper curve fits the linearity during the first 6 days; in other words, these cells have grown in the logarithmic manner during the above-said period.

Areal growth of cell colonies: To speak generally, the areal growth of the cells seems to continue longer than the increase in cell number. The area continuously expands up to nearly the 30th day of cultivation, while the cell population is likely to reach the maximum around the 10th day. The correlation between both will be discussed afterwards.

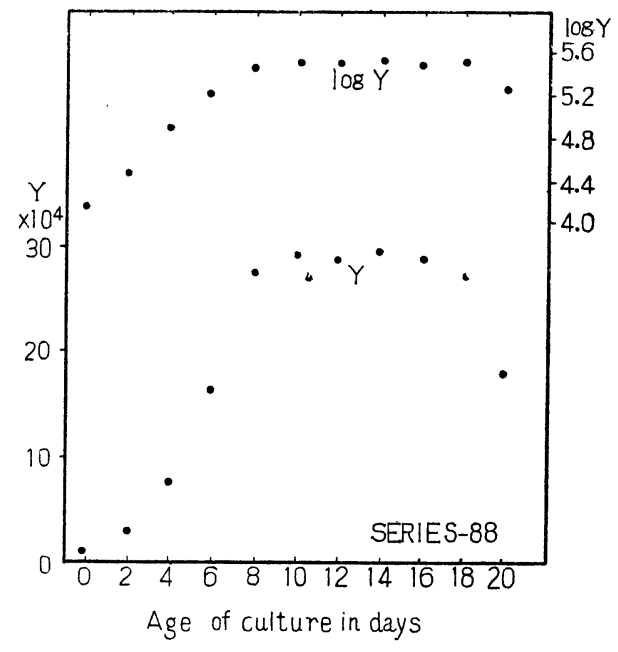

Fig. 1. Changes in the number of HeLa cells. Y represents the actual number counted.

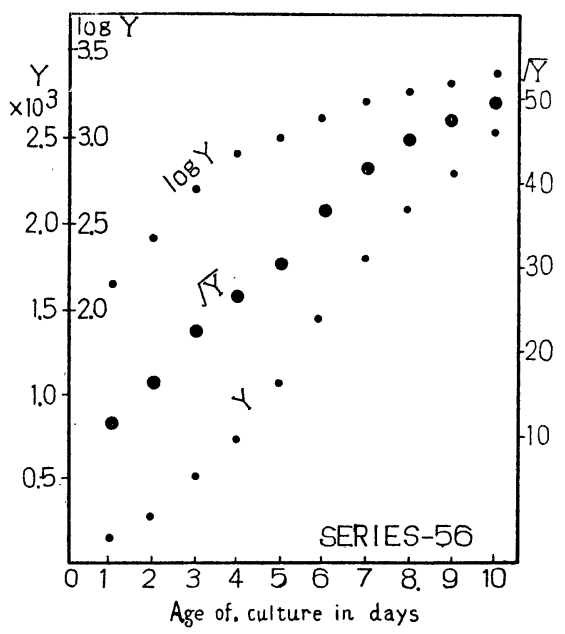

Fig. 2. Changes in the area of HeLa cell colonies. $Y$ represents the actual area measured.

In the early stage of cultivation, three sorts of measuring scales, (a) the actual areal size, (b) square root and (c) logarithm of it were used in comparison (Fig. 2). Among them the case of square root best fitted the linearity during the first 8 days. This means that the early stage of cell growth, designated the logarithmic phase by the direct counting method, might be called the "square root" phase in case the areal measurement is applied.

Besides the HeLa cells spread in a monolayer sheet keeping the thickness almost constant, and as a consequence the diameter of colony increases with a constant rate during the early stage mentioned above. It may be analogous 
to the "cubic root" phase as described by Klein et al. (1953) in their study in which the growth curve of ascites tumors in vivo was estimated on the basis of cell counting.

Correlation between colonial area and cell population: To prove their correlation more clearly, both measuring methods were applied to the same cultures. The areal growth expressed in terms of square root continued with a constant rate throughout an observation period of 10 days, while the logarithm of cell number increased linearly only up to a certain time halfway in the course. The correlation of both scales is shown in Fig. 3. A vertical line is drawn at the point of 40 on square root axis through the center of the field to divide the spots thus plotted into two distinct groups, A and B. One can find the linear correlation between both scales with a statistically high significance in Group A, which consists of the cultures within 6 days after inoculated with $10^{4}$ cells and

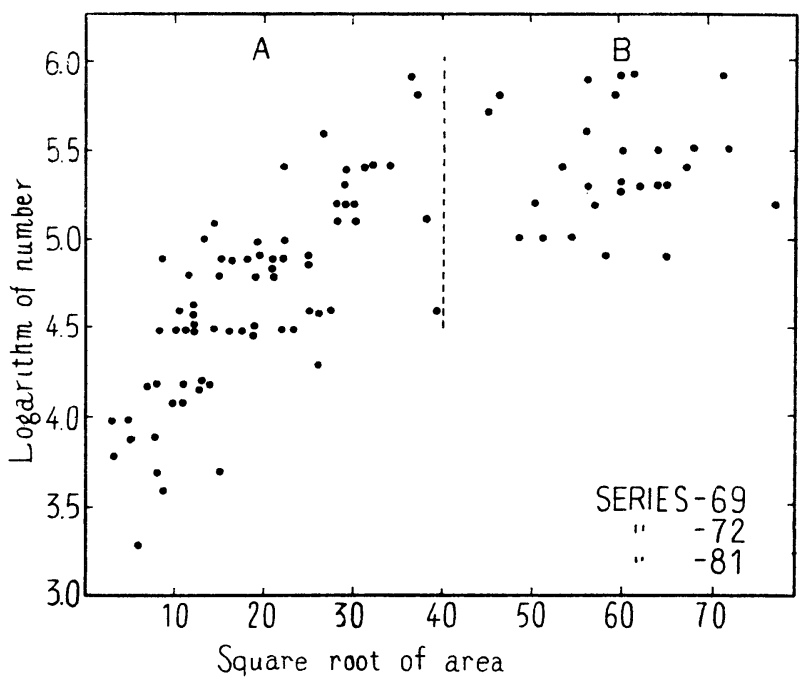

Fig. 3. Correlation between colonial area and cell population of HeLa. Observation for 10 days on several cultures with various inoculum sizes. Coefficient of correlation in Group A: 0.75 (highly significant); coefficient of correlation in Group B: 0.14 (not significant).

those within 10 days after inoculated with $5.0 \times 10^{3}$ cells, most of them belonging to the logarithmic and square root phases at the same time.

Thus it can be said that the areal expansion of cell colonies, being incapable of representing the real multiplication of cells, provides a considerably precise scale for measurement of cell growth comparable to the increase in cell number for at least a certain limited period. The biologically significant state such as the logarithmic or square root phase is to be used as a standard for experimentation in the quantitative studies of the cell growth in vitro. 


\section{SUMMARY}

It has been revealed that the area of the HeLa cell colonies expands with a constant rate in the early stage of growth. This state, referred to as the "square root" phase, accords with the logarithmic phase in the growth of cell population, providing a standard for experimentation in the quantitative studies of the cell growth in vitro.

\section{REFERENCES}

Ehrmann, R. L. and Gey, G. O. (1953) : The use of cell colonies on glass for evaluating nutrition and growth in roller-tube cultures. J. Nat. Cancer Inst., 13, 1099-1118. Evans, V. J., Earle, W. R., Sanford, K. K., Shannon, J. E. and Waltz, H. K. (1951) : The preparation and handling of replicate tissue cultures for quantitative studies. J. Nat. Cancer Inst., 11, 907-927.

Klein, G. and Révész, L. (1953): Quantitative studies on the multiplication of neoplastic cells in vivo. I. Growth curves of the Ehrlich and MC1M ascites tumors. J. Nat. Cancer Inst., 14, 229-277.

Sanford, K. K., Earle, W. R., Evans, V. J., Waltz, H. K. and Shannon, J. E. (1951) : The measurement of proliferation in tissue cultures by enumeration of cell nuclei. J. Nat. Cancer Inst., 11, 773-795.

Takano, K. and Yamada, M. (1955): Growth estimation by areal measuring of cell colonies in roller-tube cultures. Jap. J. M. Sc. \& Biol., 8, 441-449.

Takano, K., Yamada, M. and Yaginuma, K. (1956): Growth estimation of HeLa strain cells in tissue culture by nucleus enumeration method. Jap. J. M. Sc. \& Biol., 9, 17-26.

Yamada, M. and Takano, K. (1956): Growth curve of HeLa strain cells in tissue culture. Jap. J. M. Sc. \& Biol., 9, 27-39. 